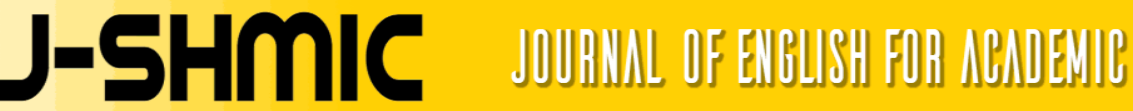

\section{Language Ability of Mild Intelectually Disabled (MID) Children: A Case Study of Dina Maramida in SLB Negeri 1 Padang}

\author{
Yasirly Amrina ${ }^{1}$ and Armitasari ${ }^{2}$ \\ Linguistics - Postgraduate Program, Faculty of Humanities \\ Andalas University, Padang \\ [1] e-mail: yasirlyamrina17@gmail.com \\ ${ }^{[2]}$ e-mail: armitasari99@gmail.com
}

\begin{abstract}
This is a case study of mild intellectually disabled children. The purpose of this study is to describe the language skills of Dina Maradina as children with mild intellectual disability (MID). This research is expected to contribute for educational purposes regarding actions that can be given to intellectually disabled children, especially mild intellectual disability to encourage increased language skills. At the stage of providing data, we used the Refer and Proficient method. The basic technique used in this method is Teknik Sadap, followed by Teknik Simak Libat Cakap (SLC), Teknik Simak Bebas Libat Cakap (SBLC), Teknik Catat and Teknik Rekam as advanced techniques. Data analysis was carried out qualitatively in the form of a description of aspects of language disorders experienced by the subject of the research by describing various symptoms and language skills owned by the subject. The results showed that the subject with mild intellectual disability has good language skills. It has several disadvantages, such as the ability of subject in emotional control, the ability in focus and concentration control and the ability in language production in terms of writing production. It is clear that the subject did not have a significant language disorder. The subject is able to communicate smoothly with the other person. This can be seen from the subject's ability to issue sentences that fit the context of the conversation. The subject is also able to show gestures, facial expressions, and usual expressions in accordance with the communication she does.
\end{abstract}

Key Words: language ability, intellectual disability, neurolinguistics

\section{Kemampuan Berbahasa pada Anak Penderita Tunagrahita Ringan: Studi Kasus Dina Maramida di SLB Negeri 1 Padang}

\begin{abstract}
Abstrak
Penelitian ini merupakan penelitian studi kasus terhadap anak tunagrahita ringan. Adapun tujuan dari penelitian ini ialah untuk mendeskripsikan kemampuan berbahasa Dina Maradina sebagai anak penyandang tunagrahita ringan. Penelitian ini diharapkan dapat memberikan sumbangsih edukatif terhadap tindakan yang dapat diberikan pada anak tunagrahita, khususnya tunagrahita ringan guna mendorong peningkatan kemampuan berbahasa. Pada tahap penyediaan data digunakan metode Simak dan Cakap. Teknik dasar yang digunakan dalam metode ini ialah teknik Sadap, diikuti dengan teknik Simak Libat Cakap (SLC), Teknik Simak Bebas Libat Cakap (SBLC), teknik Catat, dan
\end{abstract}


teknik Rekam sebagai teknik lanjutan. Analisis data dilakukan secara kualitatif yang berupa deskripsi mengenai aspek-aspek gangguan berbahasa yang dialami oleh subjek penelitian.dengan menguraikan berbagai gejala serta kemampuan berbahasa yang dimiliki subjek. Hasil penelitian menunjukkan bahwa subjek dengan gangguan tunagrahita ringan memiliki kemampuan berbahasa yang baik. Kemampuan berbahasa tersebut terdapat beberapa kekurangan, seperti kemampuan subjek dalam kontrol emosi, kemampuan subjek dalam kontrol fokus dan konsentrasi, kemampuan subjek dalam produksi bahasa dalam hal produksi tulisan. Hasil penelitian menunjukkan subjek tidak memiliki gangguan berbahasa yang signifikan. Subjek mampu berkomunikasi dengan lancar dengan lawan bicara. Hal ini terlihat dari kemampuan subjek dalam mengeluarkan kalimatkalimat yang sesuai dengan konteks pembicaraan. Subjek juga mampu menunjukkan gerak tubuh, mimik wajah, dan ekspresi sesuai dengan komunikasi yang dilakukannya.

\section{Kata Kunci: kemampuan berbahasa, tunagrahita, neurolinguistik}

\section{INTRODUCTION}

Language process covers four aspects, namely listening, speaking, reading, and writing. This aspect is obtained effectively in the family and school environment. There are two ways a child acquires a language, first it is obtained indirectly, informally, and implicitly, and second it is obtained by the presence of a teacher, classroom atmosphere, and the demand for a curriculum, as well as being carried out consciously. During education process, children's language skills can be seen according to the growth of their age and ability to communicate.

Language skill basically becomes an important aspect as a means of communication that supports many aspects of life, including in the field of education. During the educational period, children's language skills can be seen in accordance with the development of their age and the ability to communicate well when they have received language teaching. However, some children do not have the ability to communicate well during their learning process. This is caused by the difficulties in obtaining language, such as psychological disorders and behavioral development or abnormalities in children. If there is a disruption in the child's development process, this will have implications for language learning for children.

According to Chomsky, Language skills are the knowledge of languages that are abstract and unconscious. Language ability is the ability to use language that is sufficient to be seen from a language system (Kridalaksana, 1984: 95). Language skills automatically exist for someone so that s/he does not require much effort in speaking. A person's language ability is unconsciously influenced by her/his language mastery. Language mastery means well comprehended language processing and producing.

The ability of one's language begins with the mastery of the first language, the second language, the third language and so on in two ways. The first is the acquisition of language and the second is acquired by language instruction. Language acquisition is done unconsciously that is the first language or the mother 
tongue. Language learning is accomplished by teaching a language to someone. In general, the ability to master the mother tongue (first language) for a child is linear to the language acquisition. This is coherent with the opinions of psycholinguistic experts that the acquisition of the language took place from 0 to 5 years. After that, children will go to school and start with the language learning stage (Maksan, 1993: 20).

The child's ability at every stage has phases in the form of special features that are sometimes also followed by age limits. The limitation of age cannot be the main thing to look at and observe the child's ability from one step to another, because children have different capabilities and environments in the process of language development. Dardjowidjojo (2003:246) explains, one thing that needs to be understood is that this year's benchmark is very relative. The measurements should not be the calendar years, but it has to be the neurobiological years; the stage of neurobiological development in which a child is able pronounce a certain sound.

According to Tarigan (1984: 263), the development of the child's language is divided into several stages. It consists of the stage of meraban, the second stage, the holophrastic stage or the first linguistic stage, the two-stage speech, the stage of grammar development, and the stage adult language. M. Schaerleakens (in Labanursongo, 2012) divides the stage of the development of the child's language into four stages. These stages consist of:

a. Prelingual stage; occurs at the age of 0-1 year. At this stage, a prominent development is the development of comprehension, which is the passive use of language or reaction to the speaker.

b. Early lingual stage; occurs at the age of 1-2.5 years. At this stage, the child begins to say the first words, but it is not perfect in pronouncing the phoneme. This stage is also divided into three stages; stages of one word, stages of two words and stages of more than two words.

c. Stage of differentiation; occurs at the age of 2.5-5 years. The most prominent thing in this stage is the child's skills in differentiating the use of words and sentences.

d. The stage of language development; occurs after the age of five. In this period, children are considered to have mastered syntactic structures in their first language, so there are not too many problems in using the language.

The child's ability is also related and can be seen from the disruption that the child has. One possible disruption of a child is a language disorder. In language it takes the ability to put out words. Therefore, the area of Broca and Wernicke must be functioned properly. The use of both brain regions is very necessary in an effort to achieve a good and true verbal and non-verbal communication in life (Sastra, 2011: 9). If there are damages to these two areas, then there is a language disorder. Language disorders are called aphasia. Meanwhile, people with language disorders are called aphasic. 
Chaer (2003) divides aphasia into two parts namely motoric aphasia and sensoric aphasia. Motoric aphasia is divided into three parts; cortical motoric aphasia, sub-cortical motoric aphasia, and trans-cortical motoric aphasia. Cortical motoric aphasia is associated with damage caused by the loss of the ability to express the contents of the mind using words. The broken cortical area which is a place for storing passwords of words the point of damage to this type of aphasia. Sufferers can understand both spoken and written language (visual expression), but are unable to understand verbal expressions.

Sub-cortical motoric aphasia is associated with language disorders in which the damage point is the lower surface layer of the cortex or called sub-cortical. The words that will be released are still stored intact in the cortex, but those words cannot be excluded due to the breakdown of the commandment to the brain. Subcortical motoric aphasia patients cannot excrete their thoughts by using words, but can still release them by parroting.

Trans-cortical motoric aphasia occurs because the relationship between the area of broca and wernicke is disrupted. It means that interference can occur between understanding and expressing language. In general, this type of aphasia is a lesicortical that damages a portion of the Broca region, so the sufferer is able to express brief and precise words, but it is still possible to use the substitutionary words.

Meanwhile, sensoric aphasia is associated with lesicortical damage in the wernicke area of the dominant hemispherium. This area is located in the associative region between the visual area, sensoric area, motoric area, and hearing area. The damage to this area causes interference with understanding and hearing, as well as determining what is seen. In other words, the sufferer will lose understanding skill of both spoken and written language, even though the sufferer still has a verbal bulk that cannot be understood by her/himself.

In addition, Ariffudin (2013: 278-286) also classifies aphasia to be more diverse, namely; a) Front Area Aphasia, that will have difficulty producing speech due to articulation disorders that determine the movement of the utterance tools which produce the sound of the language, b) Posterior aphasia, aphasia with a disorder that occurs in the back of the brain region, which has weak language analysis power, c) Broca's aphasia, a patient with a disorder that will ultimately inhibit language production capabilities, d) Wernicke's aphasia, a damage to the area of articulation or difficulty in producing physical utterances, e) Non-fluent aphasia, that is related to the inability of sufferers to produce fluent and inadequate utterances to produce well-organized speeches, f) Fluent Aphasia, that is unable to understand speech adequately and is only able to produce meaningless sentences, and g) Dynamic aphasia, that shows the inability of sufferers to construct new syntactic structures.

In addition, there are other factors that cause a person to experience a language disorder. Chaer (2003: 148) explains further that language disorders can be grouped into two; first, due to medical factors and second, caused by social environmental factors. Disorders caused by medical factors occurred because of the abnormalities of brain function and speech equipment. On 
the other hand, the environmental factors occurred because of the form of living environments are not naturally humane.

The children who suffer a language disorder, both of their brain and psychological will disrupt. It will be difficult to obtain the language as psychological disorder and behavior development or children's abnormality. According to Sastra (2011:81) language disorders can be caused by disruption of nerve work function in the left hemisphere brain, right hemisphere brain, and other functions that result in verbal and non-verbal abilities. If there is a disruption in the child's growth and development process, it will implicate the language learning.

These language disorders will actually greatly affect the process of communication and language. Many factors influence and cause language disorders, then these factors will cause language disorders. One language disorder that occurs in children is intellectual disability (tunagrahita).

In English, tunagrahita is known as mental retardation, mental deficiency, mentally handicapped, feeble-minded, mental sub-normality (Moh. Amin, 1995: 20). Many terminologies are used to refer to the condition of intelligence below the average. In Indonesian language, the terms that are used are lemah otak, lemah ingatan, lemah pikiran, retardasi mental, terbelakang mental, cacat grahita, and tunagrahita. The other terms that are commonly used are intellectually handicapped and intellectually disabled.

Various definitions have been stated by experts. One definition that is widely accepted and become main reference is the definition formulated by Grossman (in Hallahan \&
Kauffman, 1988: 47) which is officially used by AAMD (American Association on Mental Deficiency). It is stated that mental deficiency referring to general intellectual functions that are real (significant) is below the average (normal) along with deficiencies in self-adjustment behavior reflected in the period of its development.

Associated with intellectually disabled children, the subject of this paper is Dina Maramida. She is one of the students in SLB Negeri 1 Padang with intellectual disability. Sari et al (2017: 218) reveal that due to delays in the development of intelligence, intellectual disability students will experience a variety of obstacles in an effort to meet needs, even among those who reach half or less, depending on the severity of the obstacles the child has and the attention given by their environment.

The research aims to determine the language skills of Dina Maramida as an intellectually disabled child and what actions can be given to her in order to encourage the improvement of Dina's language skills as one of the intellectually disabled children at SLB Negeri 1 Padang.

\section{METHOD}

The design of this research contains a procedure that is aimed to answer problems and to gather informations related to the research. In accordance with research actions, the research design is classified into field research which is included in qualitative descriptive research. The base of this research is on the strength of observation as the specific aspect of qualitative research; it is significant for helping readers to understand the depth of meaning and interpretation of the phenomena in this case study. This 
research is based on the natural situation in which the researchers are not trying to manipulate the research settings, but to find meaning from the actual context in order to produce a holistic perspective. Regarding its nature, this is a descriptive research. According to Sudaryanto (1992), descriptive research does not consider the correct use of language, which is the formal object of the research.

The methods and techniques used in this study are proposed by Sudaryanto (1993). This research is divided into three stages, namely the data provision stage, the data analysis stage, and the data presentation stage, as described below. At the stage of providing data the authors use the Refer and Proficient method. The method of referencing is not only listening to the language verbally, but also the language data in the form of writing. The technique used in this method is Teknik Sadap, which is tapping the use of language both in speaking and in writing. This technique is followed by advanced techniques which are Teknik Simak Libat Cakap (SLC), Teknik Simak Bebas Libat Cakap (SBLC), Teknik Catat, and Teknik Rekam. The use of advanced techniques aims to obtain data on the ability of Dina's language more fully by participating or not in communication with her. Next, it is used Teknik Catat and Teknik Rekam.

At the stage of data providing, listening and participating in the language process of the subject in the classroom were carried out. The referral method is not only obtained from listening to the spoken language, but also listening to the language data produced by the subject in the form of writing. Language data is collected to see the language skills of the subject both spoken and written. This language ability is seen from the activities of the subject while in the classroom, which is the process of interaction with teachers and researchers. The process of providing data is carried out within a period of one month, which is from April 25, 2018 to May 25, 2018. During this period of time, the provision of data in the form of direct interaction with the subject is carried out four times, or once a week. In addition, some information was also collected from observing class situations at other times.

Data analysis was carried out qualitatively in the form of descriptions of aspects of language disorders experienced by research subject. The analysis was carried out by looking at various symptoms and language skills possessed by the subject, so that it could be interpreted what language disorders that the subject had. The research design can be discussed as follows.

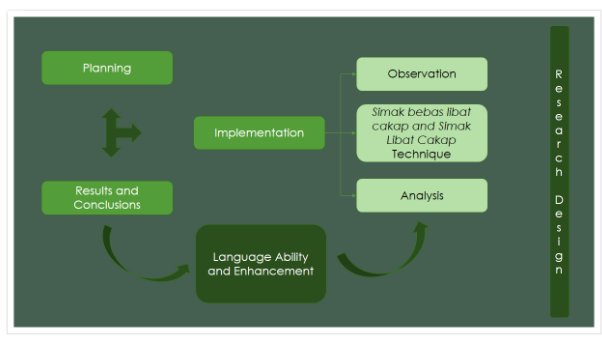

\section{FINDINGS AND DISCUSSION 3.1 General Description of the Subject}

Dina Maramida is one of the students of SLB Negeri 1 Padang which register number is 208. Dina entered this school in 2013 at the age of 10 years at the position of class $C$. When this study was conducted, Dina was in the lower grade with the same level as grade 5 elementary school. During the study, Dina was 13 years old. 
In the classroom, Dina has a friend named Puja. The placement of students in SLB N 1 Padang is an average of one or two people in each class. The placement of students in each class is based on the specific needs of the children and the abilities they have. From the description of the teacher, Dina and Puja are categorized as having the same average ability. The special needs they have are the same.

Dina is grouped in Mild Intellectual Disability (MID) children. Grouping is based on the ability that each child has. Although she is not similar with a normal child of her age, Dina and her friends can learn reading, writing, and simple counting. The subject has a high learning intensity, although her concentration often changes suddenly during the learning process.

\section{Subject Data}

\begin{tabular}{ll} 
Name : & $\begin{array}{l}\text { Dina } \\
\text { Maramida }\end{array}$ \\
$\begin{array}{l}\text { Register } \\
\text { Number : } \\
\text { Class : }\end{array}$ & 208 \\
Entry Year : & B Bottom (5) \\
Place of Birth : & Padang \\
Date of Birth : & March 10, 2003 \\
Age : & 13 years old \\
Gender : & Female \\
Religion : & Islam \\
Father's name : & Dasril \\
Mother's name & Nuraini \\
$:$ & \\
\hline Number of & 4
\end{tabular}

Siblings :

Address :

\section{Komplek \\ Perumahan \\ Pemda, Koto \\ Luar}

\subsection{Psychological and Physical Data of the Subject}

From the gradual observation, the physical data owned by the subject is normal. Similar with other normal children, the subject does not have deficiencies or abnormalities in their physical parts. The subject has a normal body like a 13-year-old child. This is consistent with the Astati's explanation (2001: 3) that the physical condition of persons with Mild Intellectual Disability shows a good state of the body, but if you do not get good practice, it is likely that the physical posture will look less harmonious.

Motoric skills related to physical subjects are also found no deficiencies or damage. The subject can move and act normally and in healthy condition. Physical movements that can be observed are she is left-handed child who tends to use her left hand in fast moving movements. She writes with her left hand and eats also using her left hand.

Furthermore, psychological data that were successfully observed during the study were:

a. Subject is able to interact and communicate with other people.

b. Subject has a high level of confidence.

c. Subject does not show shame or lack of confidence when faced with a new environment, a new situation, or with people she just knows. 
d. Subject belongs to individuals who are able to interact quickly and actively in communication.

The healthy way of life applied in school is able to be applied by the subject, but a healthy lifestyle is not reflected in the appearance of the subject. She pays less attention to her own needs in terms of cleanliness. This can be concluded when the subject is compared with her ability to pay attention to herself compared to her classmates who have a clean and neat appearance.

\subsection{Social Interaction of Subject}

During the observation, the subject has good social interaction. Communication of the subject with other people or the environment runs smoothly. In accordance with the psychic data of the subject described above, in terms of interaction and social communication, the subject does it well.

If in general, intellectually disabled children cannot take care of themselves, maintain and lead themselves, then these are not all applied to the subject. The subject is able to take care of herself and lead herself, even though she lacks in maintaining one. She is able to serve when eating her foods until she washes the food equipment that she has used. In terms of cleanliness, the subject has a slight disadvantage compared to her classmates.

The subject is more difficult to control her emotions. She shows her feelings to others actively. She also likes to talk and tell stories, which can be said to be difficult to dismiss. Her desire to tell something seems very high.

In conditions of social interaction, the subject is sometimes able to sort out what she has to do and what not to do. From the results of observations, when a lecture is held at school, she was able to control herself not to chat and do activities that were not in accordance with the rules. However, in class interactions, she sometimes loses focus.

\subsection{Language Skill}

From the results of observations during the study, the language skills owned by the subject will be grouped into several categories. The following is an explanation of the language skills of the subject.

\subsubsection{Types of Language Disorders and Speech Disorders \\ In accordance with the} problems that the subject has, the disorder affects the child's language. At the time of the research, the ubject did not have a significant language disorder. She is able to communicate smoothly with another person. She is able to issue sentences that fit the context of the conversation. She is also able to show gestures, facial mimics, and expressions according to the communication she does.

So, even in terms of speaking, the subject does not have a speech disruption. There is no visible damage or interference in producing the language of the subject's communication process. She does not appear to have deficiencies and damage to the speech tool she has.

\subsubsection{Receptive and Productive Ability}

The receptive ability owned by the subject is quite good. During the observations that have been made, the subject is able to understand and take action according to the teacher's 
instructions or the request of the other person. It's just that the subject also has a tendency to divert the topic of conversation to the things she likes at that time. Even though this tendency is quite common, she has good language understanding. This can be seen in the following speech event.

\section{Teacher : Dina, kalau makan menggunakan tangan? \\ Dina : Tangan kanan.}

With communication as above, when the subject is asked to use her right hand to hold a spoon, she obeys what the teacher says. However, the condition does not last long, she moves the spoon again to the left hand. When the teacher asked to do the right thing again, she gave an explanation with a sad expression that she had difficulty using her right hand when eating. The expression that she issued was more directed towards the expression when her right hand was sick and still forced to hold the spoon.

In terms of the productive ability of the subject, she has quite a lot of vocabulary, adequate language acquisition in various situations. In oral communication, she is able to construct a good question as well as answering other's questions. The production of language owned by the subject is good, especially in oral communication. The disadvantage experienced by the subject is the writing ability of language. She often gives rejection when asked to write something or what she says.

\section{Researcher : Namanya siapa? \\ Dina : Dina \\ Researcher : Nama lengkap, Dina? \\ Dina : Dina Maramida \\ Researcher : Coba tuliskan nama}

Dina di kertas ini.

Dina : Susah. Ndak bisa, Buk.

When asked to write down her name again, the subject still gives the same answer. Even though she finally wants to write her name after being persuaded, the results of the Dina's writing are not the same as the actual name. Likewise, when asked to spell what has been written, she has difficulty determining the letters she wrote. The subject writes the name with spelling $\mathrm{D}$ i $\mathrm{n}$ a $\mathrm{m}$ a $\mathrm{r}$ a $\mathrm{nd}$ a. She does not make a mistake when writing her name by beginning with a capital letter, but she has difficulty separating her name and writing it correctly.

\subsubsection{Left and Right Hemisphere Conditions}

The left hemisphere and right hemisphere conditions that were successfully observed were conformity with the disorder experienced by the subject. Intellectual Disability is classified as a language disorder whose disturbance lies in the left hemisphere that is related to the language production process in terms of thinking disruption. More specific, subject experienced disruption in the concentration process so that it produces language and speech that attracts more her attention.

\subsubsection{Linguistic Findings on Gender \\ There were no specific} disorders of linguistic ability to sex or gender. Subject who are in class situation that have the same gender, the findings are invisible. When observed outside the classroom, the subject does not carry out activities and responses as normal children who have been given knowledge and 
direction regarding gender. She still interacts with the opposite gender friends, but in normal conditions.

\subsubsection{Stress and Distress Conditions on Subjects}

The condition of stress and distress in the subject did not appear to have a significant disturbance. As explained in previous psychological conditions, the subject is able to control herself according to her situation. Although often experiencing a loss of focus, she can regain the focus that has been broken quickly. The subject is also able to control herself well when in various social interactions.

From the various abilities owned by the subject as described above, the subject can be categorized as a person with Mild Intellectual Disability (MID). This is in accordance with the classification of intellectually disabled children commonly used today as follows.

a. Mild Intellectual Disability with an average IQ of 70-55

b. Moderate Intellectual Disability with an average IQ of 55-40

c. Severe Intellectual Disability with an average IQ of 40-25

d. Profound Intellectual Disability with an average IQ of 25 and below.

The function in the subject's intellectual is below the average of normal children. This lack of ability is characterized by behavior that shows the subject is not or is less able to do things that her age can do. The subject acts and is able to do work by children younger than her.

\subsection{Actions in Increasing Language Ability}

Actions must be taken on the process of cognitive and social development of the subject. Apart from various actions that can be done to prevent intellectual disability, actions that must be taken to overcome and reduce these disorders are as follows.

a. Actions that must be taken in the family environment

Actions that can be taken by the family and the immediate environment of the child are: 1) giving proper treatment to normal children, 2) giving special attention to children, 3) providing adequate nutritional intake, 4) teaching various responsibilities to the child starting from themselves, 5) being able to continue the actions given in school to the child, 6) maintaining cleanliness and health of the child, 7) providing insights that can help the child to continue to adjust, and 8) etc.

b. Action to be taken in the school environment

How to meet the educational needs of intellectually disabled children includes: 1) equality of education rights with normal children, 2) equitable education services, 3) giving specific responses according to the needs of children, 4) providing practical skills to the child, 5) giving reasonable treatment, without differentiating, pampering, or alienating her in an educational environment, 6) introduce the child to a broader social environment and is possible to find in outside of the school or family environment, 7) give good quality to the body and spirit like a normal child, 8) give responsibility that can train the child, 
9) provide education for provision of the child's abilities, and 10) etc.

The actions needed and should be obtained by the subject in the school environment have been done well by the school. It is just that it is necessary to increase the level of action for subjects who already have increased abilities, as well as the application of Indonesian language in formal situations. The subject also experience less ability in Indonesian language.

\section{CONCLUSION}

From the discussion above it can be concluded that subjects with Mild Intellectual Disability (MID) have good language skills. Language skills have several disadvantages, such as the ability of subjects in emotional control, ability in focus and concentration control, and ability in language production in terms of writing production. Apart from the various disadvantages she has, the subject can be categorized as experiencing rapid development in her language skills. For people with moderate intellectual disability, the ability she has at the age of 13 is very good. The subject is able to communicate well, able to develop self-talent, and able to improve various things in her with the spirit of learning she has.

$$
\text { In improving the language }
$$

skills of intellectually disabled children, it is based on the needs of each child who has a different level of disorder. In general, the actions that can be taken to improve children's language skills are by conducting various researches that produce useful conclusions for educators and parents.

The language ability of children indirectly has become the main education in the Subject's school environment. Various language exercises in communication are taught by the school to the Subject, which are in accordance with the curriculum standards of children with special needs. Thus, the neurolinguistic researches that might be done to improve children's language skills, special needs (mental retardation) are as follows:

a. Research conducted at SLB Negeri 1 Padang on the different levels of mental retardation experienced by each child, with the aim of better handling in accordance with these levels.

b. Research conducted on the actions of parents of mentally retardation children, with the aim of parents having knowledge of parenting to the children who suffer intellectual disability.

c. Research conducted on intellectually disabled children, which is focused on the emotional control of the child.

\section{REFERENCES}

Amin, Moh. (1995). Ortopedagogik Anak Tunagrahita. Jakarta: Direktorat Jenderal Pendidikan Tinggi Departemen Pendidikan dan Kebudayaan.

Arifuddin.

Neuropsikolinguistik.

Jakarta: Rajawali Pers.

Astati. (2001). Persiapan Pekerjaan Penyandang Cacat Tunagrahita. Bandung: CV. Pendawa. 
Chaer, Abdul. (2003). Psikolinguistik: Kajian Teoritik. Jakarta: PT Rineka Cipta.

Dardjowidjojo, Soedjono. (2003). Psikolinguistik:

Pemahaman Bahasa Manusia. Jakarta: Yayasan Obor Indonesia.

Hallahan, D. P. and Kauffman, J. M. (1988). Exceptional Children Introduction to Special Education. New Jersey: Prentice Hall International.

Kridalaksan, Harimurti. (1984). Kamus Linguistik. Jakarta: PT Gramedia Pustaka Utama.

Maksan, Marjusman. (1993). Psikolinguistik. $\quad$ Padang: IKIP Padang Press.

Mumpuniarti. (2000). Penanganan Anak Tunagrahita: Kajian Dari Segi Pendidikan Sosial Psikologi dan Tindak Lanjut Usia Dewasa. UNY: Yogyakarta.
Sari, at all. (2017). "Pendidikan Bagi Anak Tunagrahita (Studi Kasus Tunagrahita sedang di SLB N Purwakarta)". Jurnal Penelitian dan PKM. Vol 4. No. 2. Hal 129-389.

Sastra, Gusdi. (2011). Neurolinguistik Suatu Pengantar. Bandung: Alfabeta.
Sudaryanto. (1992). Metode Linguistik: $\quad \mathrm{Ke} \quad$ Arah Memahami Metode Linguistik. Yogyakarta: Gadjah Mada University Press.

Sudaryanto. (1993). Metode dan Aneka Teknik Anlisis Bahasa: Pengantar Penelitian Wahana Kebudayaan Secara Linguistik. Yogyakarta: Duta Wacana University Press.

Tarigan, Henry Guntur. (1986). Psikolinguistik. Bandung: Angkasa. 